\title{
PENGARUH MODEL PROBLEM BASED LEARNING (PBL) TERHADAP KEMAMPUAN KOMUNIKASI SISWA MATERI POKOK LARUTAN ELEKTROLIT DAN NON-ELEKTROLIT
}

\section{THE INFLUENCE OF PROBLEM BASED LEARNING (PBL) MODEL ON STUDENT'S COMMUNICATION SKILLS IN SUBJECT MATTER OF ELECTROLYTE AND NON-ELECTROLYTE SOLUTION}

\author{
Iftitahurrahimah ${ }^{1}$, Yayuk Andayani², Syarifa Wahidah Al Idrus ${ }^{2}$ \\ ${ }^{1}$ Mahasiswa Prodi Pendidikan Kimia FKIP Universitas Mataram, Indonesia \\ ${ }^{2}$ Dosen Prodi Pendidikan Kimia FKIP Universitas Mataram, Indonesia \\ email: iftitahurrahimahsofyan1997@gmail.com
}

Diterima: 15 Juli 2019. Disetujui: 15 Juli 2019. Dipublikasikan: 9 Januari 2020

\begin{abstract}
Abstrak: Penelitian ini bertujuan untuk mengetahui pengaruh model Problem Based Learning (PBL) terhadap kemampuan komunikasi siswa pada materi pokok larutan elektrolit dan non-elektrolit. Penelitian quasy eksperimen menggunakan rancangan post-test only control grup design dengan populasi seluruh siswa kelas $\mathrm{X}$ MIA SMAN 8 MATARAM. Kelas X MIA 3 sebagai kelas eksperimen yang diajarkan dengan model Problem Based Learning (PBL) dan kelas X MIA 4 sebagai kelas kontrol yang diajarkan dengan model konvensional ditentukan dengan teknik purposive sampling. Data kemampuan komunikasi siswa dikumpulkan menggunakan tes tulis untuk kemampuan komunikasi tulisan, sedangkan lembar observasi untuk data kemampuan komunikasi lisan. Hasilnya menunjukkan bahwa rata-rata kemampuan komunikasi tulisan siswa di kelas eksperimen yaitu 75,15 dengan kriteria tinggi, sedangkan di kelas kontrol 57,10 dengan kriteria sedang, kemampuan komunikasi lisan siswa di kelas eksperimen yaitu 10,54 dengan kriteria sangat rendah dan di kelas kontrol yaitu 5,18 dengan kriteria sangat rendah. Berdasarkan uji hipotesis menggunakan uji-t pada taraf signifikan 5\% menunjukkan bahwa model Problem Based Learning memberikan pengaruh terhadap kemampuan komunikasi tulisan siswa materi pokok larutan elektrolit dan non-elektrolit. Uji hipotesis menggunakan uji-t juga menunjukkan bahwa model Problem Based Learning memberikan pengaruh terhadap kemampuan komunikasi lisan siswa materi pokok larutan elektrolit dan non-elektrolit.
\end{abstract}

Kata kunci: Problem Based Learning, kemampuan komunikasi

\begin{abstract}
The purpose of this research is to determine the extent of a influence Problem Based Learning (PBL) model is based on student's writing communication skills and to determine the extent of a influence Problem Based Learning (PBL) model is based on student's verbal communication skills in subject matter of electrolyte and non-electrolyte solution. Quasi experiment research uses post-test control group design with population of X class in SMAN 8 Mataram. X MIA 3 as an experiment class taught with Problem Based Learning (PBL) model and X MIA 4 as a control class taught with conventional model depend with purposive sampling technique. Student communication skill data collected with written test for written of communication skills while the observation sheet collected for verbal communication skills data. The result showed that the average of student written communication skills in the experiment class was 75,15 which is highly recommended, whereas in control class 57.10 with the medium criteria. The student of verbal communication skill in experiment class was 10,54 which is very low criteria and in control class was 5.18 with very low criteria too. Based on the test of hypotheses using t-test at a significant 5\% indicate that Problem Based Learning (PBL) model provide an influence based on students writing communication skills in subject matter of electrolyte and non-electrolyte solution. The test of hypotheses using t-test indicate that Problem Based Learning (PBL) model provide an influence based on student's verbal communiation skills in subject matter of electrolyte and non-electrolyte solution.
\end{abstract}

Keywords: Problem based learning, communication skills

\section{PENDAHULUAN}

Komunikasi dibagi menjadi dua yaitu komunikasi verbal dan komunikasi nonverbal. Komunikasi verbal adalah komunikasi yang menggunakan kata-kata, baik itu secara lisan maupun tulisan [Kurniati 1]. Dalam pembelajaran sains kemampuan berkomunikasi secara lisan biasanya terjadi pada saat diskusi kerena terjadi proses interaksi dalam mengerjakan soal, setiap anggota kelompok akan berinteraksi secara langsung dalam kelompok. Interaksi ini bermaksud agar setiap anggota kelompok dapat berhubungan, saling membantu, toleran dan berkomunikasi secara efektif dan etis. Indikator komunikasi lisan meliputi mengemukakan pendapat, menanggapi pendapat, mengajukan pertanyaan dan menjawab pertanyaan 
[Yusefni 2]. Dalam penelitian Wasonowati [3] menyatakan bahwa penerapan model Problem Based Learning (PBL) yang didukung oleh teori perkembangan Piaget yang menyatakan bahwa perkembangan kognitif siswa bergantung pada keaktifan dalam berintraksi serta memanfaatkan pengalaman nyata.

Berdasarkan hasil observasi dan wawancara pada guru mata pelajaran kimia dan siswa di SMAN 8 Mataram, menyatakan bahwa ilmu kimia menarik tetapi sulit dipahami sehingga komunikasi siswa dengan guru masih tergolong rendah yang menyebabkan siswa cenderung lebih banyak diam dan berani mengemukakan pendapat ketika benarbenar dipaksa oleh guru. Selain itu guru sering menggunakan model konvensional dengan metode ceramah yang berpusat pada guru sehingga siswa cenderung pasif dalam berkomunikasi saat peroses pembelajaran. Fakta lain menunjukkan rata-rata hasil belajar peserta didik pada mata pelajaran kimia kelas X MIA SMAN 8 Mataram masih dibawah Kriteria Ketuntasan Minimal (KKM).

Menurut Sari [4] salah satu faktor yang menyebabkan nilai siswa masih dibawah KKM yaitu peserta didik sebagai pelaku dalam kegiatan belajar tidak mempunyai kesadaran, kemauan dan keterlibatan dalam pembelajaran. Pembelajaran akan berhasil jika peserta didik secara sadar terlibat dalam proses pembelajaran. Pentingnya komunikasi sebagai prestasi akademik juga tertuang dalam salah satu kompetensi lisan kurikulum yang merupakan bagian dari kurikulum berbasis kompetensi yakni siswa menggunakan bahasanya sendiri untuk memahami, mengembangkan dan mengkomunikasikan gagasan dan informasi, serta untuk berinteraksi dengan orang lain [Astuti 5]. Komunikasi juga berperan penting dalam membantu siswa memahami materi yang sedang di pelajari. Siswa juga harus diperkenankan mempersembahkan ide-ide mereka secara tertutur dan menulis. indikator komunikasi lisan yang diukur dalam penelitian ini yaitu mengemukakan pendapat, menanggapi pendapat, mengajukan pertanyaan, menjawab pertanyaan [Yusefni 2]. Sedangkan indikator komunikasi tulisan siswa yaitu menyajikan pernyataan secara tertulis, memberi alasan atau bukti terhadap kebenaran solusi [Fatimah 6]. Dengan menerapkan pembelajaran yang tepat misalnya model Problem Based Learning (PBL) diharapkan dapat melatih kemampuan komunikasi siswa.

Model Problem Based Learning (PBL) merupakan salah satu model pembelajaran yang memiliki ciri khas yaitu selalu dimulai dengan masalah dan berpusat pada masalah. Model PBL membuat siswa mendapatkan pengalaman belajar yang lebih bermakna karena siswa terlibat secara langsung dalam berbagai tahapan pembelajaran. selain itu, siswa juga dapat bertanggung jawab untuk mengingat pengetahuan yang diperoleh sehingga siswa dapat membangun pemahamannya sendiri terhadap materi yang diajarkan [7-10]. Selain itu, dengan model Problem Based Learning juga dapat meningkatkan antusias siswa dalam berdiskusi, tekun mengerjakan soal dan antusias siswa dalam mempersentasikan atau mengemukakan pendapat sesuai dengan pemahamannya. Oleh karena itu tujuan penelitian ini adalah untuk mengetahui ada tidaknya pengaruh model Problem Based Learning (PBL) terhadap kemampuan komunikasi tulisan siswa materi pokok larutan elektrolit dan non-elektrolit dan untuk mengetahui ada tidaknya pengaruh model Problem Based Learning (PBL) terhadap kemampuan komunikasi lisan siswa materi pokok larutan elektrolit dan nonelektrolit.

\section{METODOLOGI}

Penelitian ini merupakan penelitian quasi eksperimen (eksperimen semu) dengan desain Posttest Only Control Group Design dengan Desain ini melibatkan 2 kelas, yaitu kelas eksperimen yang memperoleh pembelajaran dengan model Problem Based Learning, dan kelas kontrol memperoleh pembelajaran dengan model Konvensional. Desain penelitian yang dilakukan sesuai dengan Tabel 2 .

Tabel 2 Rancangan Penelitian

\begin{tabular}{clcc}
\hline \multirow{2}{*}{ Kelas } & Perlakuan & \multicolumn{2}{c}{ Pengumpulan Data } \\
\cline { 3 - 4 } & & $\begin{array}{c}\text { Komunikasi } \\
\text { Tulisan }\end{array}$ & $\begin{array}{c}\text { Komunikasi } \\
\text { Lisan }\end{array}$ \\
\hline Ekperimen & $\begin{array}{l}\text { Model Problem } \\
\text { Based Learning }\end{array}$ & Posttest & $\begin{array}{c}\text { Lembar } \\
\text { Observasi }\end{array}$ \\
\hline Kontrol & Model & Posttest & Lembar \\
& konvensional & & Observasi \\
\hline
\end{tabular}

Variabel bebas dalam penelitian ini adalah model Problem Based dan model konvensional, sedangkan variabel terikat adalah kemampuan berkomunikasi tulisan siswa dan kemampuan komunikasi lisan siswa.

Populasi pada penelitian ini yaitu seluruh siswa kelas X MIA SMAN 8 Mataram yang berjumlah 172 dari 5 kelas MIA dan sampel penelitian ini yaitu siswa kelas X MIA 3 dan X MIA 4 yang diperoleh dengan teknik purposive sampli $n g$ [11].

Data kemampuan komunikasi tulisan siswa diperoleh dari tes dalam bentuk soal uraian, sedangkan untuk data komunikasi lisan siswa diperoleh dari lembar observasi pada saat proses pembelajaran berlangsung. Uji validitas isi dalam penelitian ini menggunakan statistik Aiken's V, validitas butir soal menggunakan rumus koefisien korelasi Product Moment dan untuk menguji reabilitas instrumen menggunakan rumus Alpha Cronbach. Uji normalitas data menggunakan rumus Chi kuadrat dan homogenitasnya menggunakan uji- 
$\mathrm{F}$, sedangkan untuk uji hipotesis dalam penelitian ini menggunakan uji-t (11].

\section{HASIL DAN PEMBAHASAN}

Penelitian ini dilakukan untuk mengetahui ada tidaknya pengaruh model Problem Based Learning (PBL) terhadap kemampuan komunikasi tulisan siswa materi pokok larutan elektrolit dan non-elektrolit dan untuk mengetahui ada tidaknya pengaruh model Problem Based Learning (PBL) terhadap kemampuan komunikasi lisan siswa materi pokok larutan elektrolit dan non-elektrolit. Data dalam penelitian ini yaitu kemampuan komunikasi tulisan siswa dan kemampuan komunikasi lisan siswa.

\section{Kemampuan Komunikasi Tulisan}

Peneliti memberikan tes evaluasi berupa post-test pada kelas eksperimen dan kelas kontrol yang menjadi sampel pada penelitian ini. Post-test ini dilakukan sebagai tahap evaluasi untuk mengukur kamampuan komunikasi tulisan siswa setelah diberikan pembelajaran sebelumnya. Hasil posttest ini kemudian digunakan dalam uji hipotesis agar pengaruh model Problem Based Learning terhadap kemampuan komunikasi tulisan siswa dapat diketahui secara lebih jelas. Hasil uji hipotesis menggunakan uji-t (Polled Varians) menunjukkan penerapan model Problem Based Learning memberikan pengaruh terhadap kemampuan komunikasi tulisan siswa pada materi pokok larutan elektrolit dan non-elektrolit.

Berdasarkan data post-test yang di tabulasi menjadi data kemampuan komunikasi tulisan siswa. Hasil kemampuan komunikasi tulisan siswa per indikator dapat dilihat pada Gambar 1.

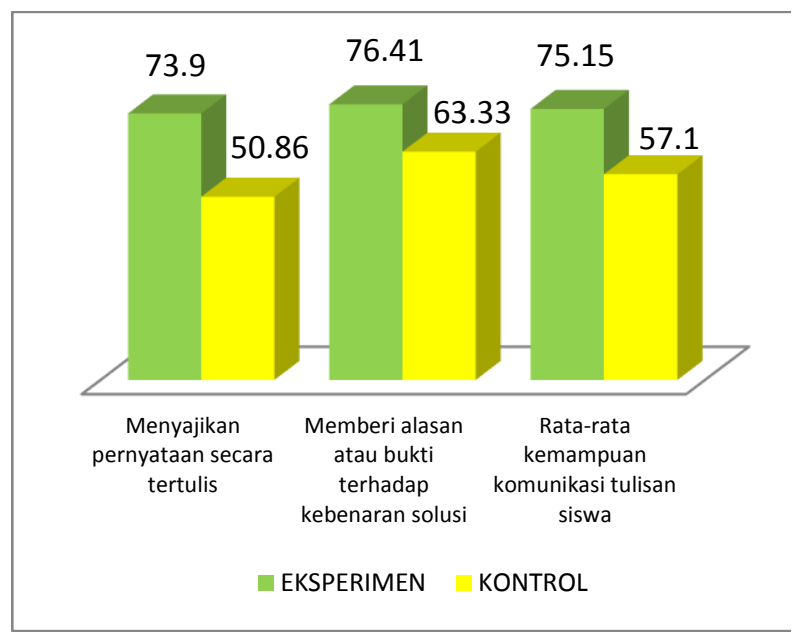

\section{Gambar 1 Data Hasil Kemampuan Komunikasi Tulisan Siswa Per Indikator}

Berdasarkan Gambar 1 di atas menunjukkan bahwa persentase tertinggi diperoleh pada indikator memberi alasan atau bukti terhadap kebenaran solusi pada kelas eksperimen sedangkan persentase terendah diperoleh pada indikator menyajikan pernyataan secara tertulis dengan benar di kelas kontrol. Gambar 1 juga terlihat bahwa ada perbedaan kemampuan komunikasi tulisan siswa per aspek di kelas eksperimen dan kelas kontrol. Diantara dua aspek yang diukur dari kemampuan komunikasi tulisan terlihat pada kelas eksperimen selalu lebih baik dibandingkan kelas kontrol, Hal ini di sebabkan karena model Problem Based Learning yang merupakan metode instruksional yang menantang siswa agar belajar untuk belajar, bekerja sama dalam kelompok untuk mencari solusi bagi masalah yang nyata, sehingga masalah ini digunakan untuk mengingat, meningkatkan rasa keingintahuan serta kemampuan analitis dan inisiatif atas materi pembelajaran [13]. Menurut Utomo [14] model Problem Based Learning (PBL) merupakan salah satu model pembelajaran yang menuntut aktivitas mental siswa untuk memahami suatu konsep pembelajaran melalui situasi dan masalah yang disajikan pada awal pembelajaran dengan tujuan untuk melatih siswa menyelesaikan masalah dengan menggunakan pemecahan masalah. Sehingga penggunaan model Problem Based Learning di dalam kelas membuat siswa untuk ikut terlibat langsung dalam proses pembelajaran jika dibandingkan dengan penggunaan model konvensional. Hal tersebut telah sejalan dengan karateristik dari model Problem Based Learning, pembelajaran dengan menerapkan model tersebut memberikan kesempatan kepada siswa untuk terlibat langsung dalam menemukan solusi dari masalah yang ada. Amin [15] juga menyatakan bahwa adanya kebiasaan belajar yang efektif akan membantu siswa untuk mendapatkan hasil belajar yang baik karena semakin baik kebiasaan belajar siswa maka semakin baik pula prestasi akademik yang diraih.

Hasil analisis data juga menunjukkan bahwa terdapat pengaruh model Problem Based Learning terhadap kemampuan komunikasi tulisan siswa materi pokok larutan elektrolit dan nonelektrolit yang ditunjukkan oleh nilai $t_{\text {hitung }}$ sebesar 4,76 lebih besar dari $t_{\text {tabel }}$ sebesar 1,671 pada taraf signifikan $5 \%$.

Penggunaan model Problem Based Learning di dalam kelas membuat siswa untuk ikut terlibat langsung dalam proses pembelajaran jika dibandingkan dengan penggunaan model konvensional. Hal tersebut telah sejalan dengan karateristik dari model Problem Based Learning, pembelajaran dengan menerapkan model tersebut memberikan kesempatan kepada siswa untuk terlibat langsung dalam menemukan solusi dari masalah yang ada. Tercapainya hasil postest yang lebih tinggi pada kelas eksperimen dibandingkan dengan kelas kontrol serta berdasarkan uji hipotesis uji-t menunjukkan bahwa komunikasi tulisan siswa pada kelas eksperimen lebih tinggi dibandingkan dengan kelas kontrol. Hal ini disebabkan karena proses 
pembelajaran menggunakan model Problem Based Learning dapat meningkatkan perhatian dan fokus siswa serta dapat meningkatkan komunikasi siswa, meningkatkan partisipasi siswa secara aktif dalam pembelajaran, dan menumbuhkan motivasi siswa dalam memahami suatu permasalahan secara lebih mendalam, karena dengan model Problem Based Learning membuat siswa cenderung tertarik dan penasaran dengan masalah yang diberikan.

\section{Kemampuan Kmunikasi Lisan Siswa}

Komunikasi lisan siswa diukur melalui lembar observasi yang dinilai lansung pada saat pembelajaran berlangsung yang bertujuan untuk mengetahui pengaruh model Problem Based Learning terhadap kemampuan komunikasi lisan siswa serta untuk mengetahui kriteria komunikasi lisan siswa, baik di kelas eksperimen maupun di kelas kontrol. Nilai rata-rata komunikasi lisan siswa per aspek setelah dilakukan perhitungan baik pada kelas eksperimen maupun kelas kontrol yang disajikan dalam Gambar 2.

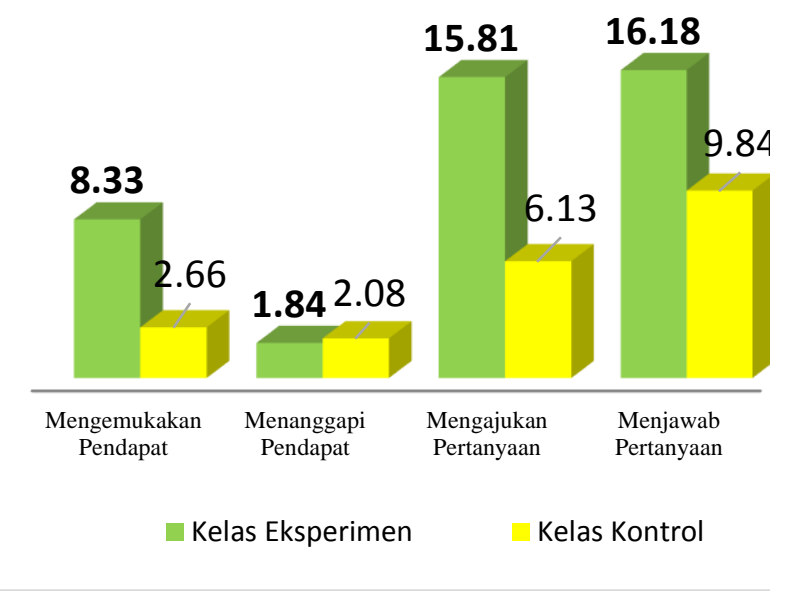

\section{Gambar 2 Kemampuan Komunikasi Lisan SiswA Per Indikator}

Berdasarkan Gambar 2 di atas terlihat bahwa ada perbedaan kemampuan komunikasi lisan siswa per indikator di kelas eksperimen dan kelas kontrol. Diantara empat indikator dari kemampuan komunikasi lisan yang diukur ternyata tiga dari empat indikator terlihat kelas eksperimen lebih baik, tetapi pada salah satu indikator yaitu indikator menanggapi pendapat kelas eksperimen terlihat tidak lebih baik dari kelas kontrol. Hal tersebut dapat terjadi karena dengan menggunakan model Problem Based Learning (PBL) siswa mencari sendiri solusi dari permasalahan yang disajikan oleh guru serta saling bekerjasama dalam kelompoknya untuk pemecahan masalah sehingga siswa lebih percaya diri untuk menyampaikan apa yang mereka ketahui. Pada model PBL setiap siswa mempunyai tanggung jawab terhadap penguasaan materi, karena siswa dituntut agar dapat mengeluarkan pendapatnya dalam memberikan solusi untuk permasalahan yang telah diberikan oleh guru pada LKS, karena dengan penguasaan materi yang baik akan mempermudah siswa dalam penyampaian pendapat untuk menemukan solusi pemecahan masalah yang ada dalam LKS.

Ketika melakukan presentasi dan tanya jawab pada anggota kelompok lain siswa dapat menjelaskan secara lancar, jelas dan sesuai teori agar siswa dari kelompok lain lebih mudah memahami apa yang disampaikan. Pada penelitian ini sebagian siswa (pembicara) dengan pemahaman isi meteri yang baik dapat lebih mudah dipahami oleh siswa lain (pendengar). Hal ini dapat dilihat berdasarkan data hasil penelitian komunikasi lisan rata-rata indikator mengemukakan pendapat dan menanggapi pendapat. Pada indikator mengemukakan pendapat kelas eksperimen data nilai rata-rata 8,33 sedangkan pada kelas kontrol yaitu 2,66 sehingga dapat dilihat bahwa rangkaian proses komunikasi di kelas eksperimen lebih berjalan baik di bandingkan kelas kontrol, apabila siswa (pembicara) yang memahami isi materi dapat menyapaikan materi dengan lancar dan jelas sehingga siswa lain (pendengar) mampu menerima dan memahami materi yang disampaikan dengan baik ketika memprsentasikan hasil kerja kelompoknya.

Hal ini diperkuat dengan penelitian Sari [4] yang menyatakan bahwa tingginya nilai rata-rata kemampuan komunikasi lisan siswa pada kelas eksperiem dari pada kelas kontrol yaitu karena model Problem Based Learning yang digunakan untuk merangsang siswa terlibat aktif dalam peecahan masalah sehingga dapat melatih komunikasi lisan siswa baik pada saat diskusi atau pada saat persentasi didepan kelas. Rahmadani [12] juga menyatakan bahwa apabila aktivitas siswa dalam pembelajaran hanya sebatas pada aktivitas mendengar guru dan diskusi saja, tidak ada aktivitas lain yang mendukung proses pembelajaran maka aktivitas pembelajaran siswa tidak optimal. Oleh karena itu, cara untuk meningkatkan aktivitas belajar siswa yaitu dengan menggunakan pendekatan berbasis masalah yang mengacu pada siswa yang diarahkan langsung untuk terlibat dalam pemecahan masalah dalam pembelajaran. Sehingga siswa merasa tertantang untuk memecahkan masalah sehingga siswa mampu berperan aktif dalam proses pembelajaran.

Yuniarti [17] menyatakan bahwa penerapan model Problem Based Learning membuat siswa tidak hanya menghafal materi yang diberikan guru, tetapi siswa dapat mengembangkan kemampuan berpikirnya menjadi berpikir tingkat tinggi, karena dalam merumuskan beberapa alternatif pemecahan masalah siswa memilih salah satu alternitif yang paling kuat yaitu dengan cara diskusi atau melakukan melakukan tanya jawab. Paloloang [18] 
juga menyatakan bahwa tanya jawab dan berdiskusi yaitu cara menguji keakuratan dari solusi dan melakukan refleksi terhadap pemecahan masalah yang dilakukan. Kemampuan komunikasi lisan siswa dapat terlatih dengan baik karena dalam pembelajaran menggunakan PBL mengutamakan komunikasi yang baik antar siswa dalam memecahkan masalah untuk mencapai tujuan bersama. Adanya tanya jawab dalam diskusi juga dapat membawa pengaruh yang positif terhadap kemampuan komunikasi lisan siswa. Kemampuan komunikasi lisan yang terlatih dengan baik akan mempermudah siswa dalam menyapaikan informasi-informasi yang didapat sehingga akan mempermudah siswa lain untuk memahami apa yang disapaikan pada saat melakukan diskusi serta dapat meningkatkan penguasaan materi pembelajaran yang didapatkan.

Berdasarkan hasil analisis data juga menunjukkan bahwa terdapat pengaruh model Problem Based Learning terhadap kemampuan komunikasi lisan siswa materi pokok larutan elektrolit dan non-elektrolit yang ditunjukkan oleh nilai thitung sebesar 1,91 lebih besar dari $t_{\text {tabel }}$ sebesar 1,671 pada taraf signifikan $5 \%$.

\section{KESIMPULAN}

Berdasarkan data hasil penelitian dan pembahasan, dapat disimpulkan bahwa model Problem Based Leaning memberikan pengaruh terhadap kemampuan komunikasi tulisan siswa pada materi pokok larutan elektrolit dan non-elektrolit dan model Problem Based Leaning memberikan pengaruh terhadap kemampuan komunikasi lisan siswa pada materi pokok larutan elektrolit dan nonelektrolit.

\section{DAFTAR PUSTAKA}

[1] Kurniati, D., P., Y. 2016. Modul Komunikasi Verbal dan Nonverbal. Denpasar.

[2] Yusefni, 2015. Analisis Hubungan Ktivitas Writing to Learn dengan kemampuan Berkomunikasi Lisan Siswa dalam Pembelajaran Science Writing Heuristic. Bandung.

[3] Wasonowati, R. R. 2014. Penerapan Model Problem Based Learning (PBL) Pada Pembelajaran Hukum-hukum Dasar Kimia Ditinjau Dari Aktivitas dan Hasil Belajar Siswa Kelas X IPA SMA Negeri 2 Surakarta Tahun Pelajaran 2013/2014. Jurnal Pendidikan Kimia. 3(3): 66-75.

[4] Sari, P., I. 2018. Pengaruh Model Problem Based Learning Terhadap Kemampuan Komunikasi Lisan dan Hasil Belajar Kognitif Siswa SMA Negeri !5 Bandar Lampung Pada Materi Virus. Kripsi. Universitas Islam Negeri Raden Intan Lampung.

[5] Astuti, A. 2011. Peran Kemampuan Komunikasi Matematika Terhadap Prestasi
Belajara Matematika Siswa. Jurnal Formatif. 2 (2): 102- 110 .

[6] Fatimah, F. 2012. Kemampuan Komunikasi Matematis Dan Pemecahan Masalah Melalui problem Based-Learning. Jurnal Penelitian dan Evalasi Pendidikan. 16 (1). 249-260.

[7] Fahmidani,Y., Andayani, Y., Purwoko, A.A. (2019). Pengaruh Model Pembelajaran Berbasis Masalah Dengan Media Lembar Kerja Terhadap Hasil Belajar SIswa SMA. Chemistry Education Practice. 2 (1). 1-5.

[8] Fathonah, N., Ibnu, S., \& Suharti, S. (2016). Pengaruh pembelajaran berbasis pemecahan masalah berbantuan jurnal belajar terhadap kemampuan metakognitif. Jurnal Pijar Mipa, 11(1).

[9] Safitri, E. H., Siahaan, J., \& Al Idrus, S. W. (2015). Studi Komparasi Hasil Belajar Kimia Pada Materi Koloid Menggunakan Model Pembelajaran Berbasis Proyek dan Model Pembelajaran Berbasis Masalah Siswa Kelas XI IPA MAN 2 Mataram Tahun Ajaran 2013/2014. Jurnal Pijar Mipa, 10(1).

[10] Susilawati, S., Jamaluddin, J., \& Bachtiar, I. (2017). Pengaruh Model Pembelajaran Berbasis Masalah (Pbm) Berbantuan Multimedia Terhadap Kemampuan Berpikir Kritis Peserta Didik Kelas Vii SMP Negeri 2 Mataram Ditinjau Dari Kemampuan Akademik. Jurnal Pijar Mipa, 12(2), 64-70.

[11]Sugiyono. 2017. Statistik Untuk Penelitian. Bandung: Alfabeta.

[12] Wulandari, B. 2013. Pengaruh Problem Based Learning Terhadap Hasil Belajar Ditinjau Dari Motivasi Belajar PLC di SMK. Jurnal Pendidikan Vokasi.3 (2): 178-191.

[13] Utomo, T. 2014. Pengaruh Model Pembelajaran Berbasis Masalah (Problem Based Learning) Terhadap Pemahaman Konsep dan Kemampuan Berpikir Kreatif Siswa Kelas VIII Semester Gasal SMPN 1 Sembermalang Kabuten Situbondo Tahun 2012/2013. Jurnal Edukasi UNEJ. 1 (1). 5-9.

[14] Amin, V, E. Andayani, Y. Sukib, S. 2018. Hubungan Antara Minat Belajar dan Kebiasaan Belajar Terhadap Hasil Belajar Kimia Siswa Kelas XI IPA SMA Mataram Tahun Ajaran 2017/2018. Chemistry Education Practice. 1 (1). 1- 7.

[15] Ramdani, N. 2017. Peningkatan Aktivitas Belajar Matematika Melalui Pendekatan Problem Based Learning Bagi Siswa Kelas 4 SD. Jurnal Pendidikan dan Kebudayaan. 7 (3). 241- 250.

[16] Yuniarti, T. Hadi, S. 2015. Peningkatan Kemampuan Analisis Pokok Bahasan Masalah Ekonomi Dengan ModelPembelajaran Problem Bades Learning (PBL) Siswa SMA Negeri 1 Bandongan Kabupaten Magelang. Jurnal 
J. Pijar MIPA, Vol. 15 No.1, Januari 2020: 7-12

Pendidikan Ekonomi Pendidikan. 10 (1). 7687.

[17] Paloloang, M, F,B. 2014. Penerapan Model Problem Based Learning (PBL) untuk Meningkatkan Hasil Belajar Siswa Pada Materi Panjang Garis Singgung Persekutuan Dua Lingkaran di Kelas VIII SMP Negeri 19 Palu. Jurnal Elektronik Pendidikan Matematika Tadulako. 2 (1). 1- 11. 